๑ Entomologica Fennica. 30 October 2002

\title{
Monoctonus leclanti sp. n. (Hymenoptera: Braconidae: Aphidiinae) from high-montane areas of southeastern Europe, and key to related species
}

\author{
Željko Tomanović, Petr Starý \& Olivera Petrović
}

Tomanović, Ž., Starý, P. \& Petrović, O. 2002: Monoctonus leclanti sp. n. (Hymenoptera: Braconidae: Aphidiinae) from high-montane areas of southeastern Europe, and key to related species. — Entomol. Fennica 13: 159-162.

Monoctonus leclanti sp. n., a parasitoid of Delphiniobium junackianum Karsch. (Hemiptera: Aphididae) on Aconitum toxicum bosniacum and Aconitum pentheri in the high mountains of the Balkans is described. The species is an additional member of the high-montane aphid parasitoid guild determined in the area. A key to related species is included.

Željko Tomanović, Institute of Zoology, Faculty of Biology, University of Belgrade, Studentski trg 16, 11000 Belgrade, Yugoslavia; E-mail: ztoman@bf.bio.bg.ac.yu

Petr Stary, Institute of Entomology, Academy of Sciences of the Czech Republic, Branišovská 31, 37005 České Budějovicé, Czech Republic; E-mail: stary@entu.cas.cz

Olivera Petrovic, Department of Plant Protection, Faculty of Agriculture, University of Belgrade, Nemanjina 6, 11081 Zemun, Yugoslavia; E-mail: petrovic@agrifaculty.bg.ac.yu

Received 9 April 2002, accepted 8 August 2002

\section{Introduction}

The great variety of habitats and high diversity of plant species in southeastern Europe, originating from its complex geological history, has apparently contributed to the great diversity of aphids and their parasitoids in this area. Investigations of aphid parasitoids in high-montane areas and some refugial canyons and gorges of southeastern Europe have revealed many new and rare aphid parasitoid species and associations (Stary et al. 1998, Tomanović et al. 1998, Tomanović \& Brajković 2000, Kavallieratos et al. 2001, Tomanović \& Starý 2001, Tomanović 2002). This ongoing research has also led to the discovery of an undescribed Monoctonus species, which is a member of the high-montane parasitoid guild in the area. The species is described in this paper.

\section{Material and methods}

Aphid parasitoid material was collected on Mt. Kopaonik (1450 m a.s.1.) and Mt. Durmitor (1400 m a.s.1.). Two aphid host plants, Aconitum toxicum bosniacum and Aconitum pentheri, were sampled for aphid parasitoids. Aconitum toxicum bosniacum is a montane-subalpine species, distributed in mainly humid, calcareous habitats of the Carpathians and montane areas of the western Balkan Peninsula, while Aconitum pentheri is an endemic plant of central Balkan mountains (Gajić \& Niketić 1992). 


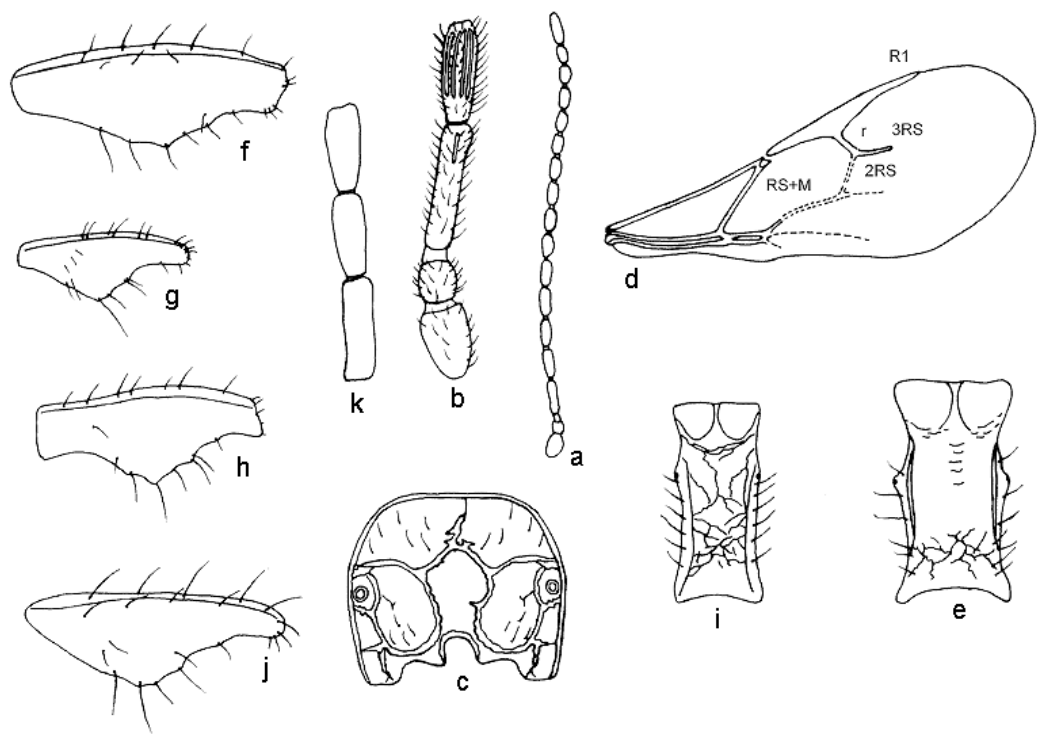

Fig. 1. a-f. Monoctonus leclanti sp. n., female. - a. Antenna. - b. Base of antenna $\left(F_{1}\right.$ and $\left.F_{2}\right)$. $-c$. Propodeum. - d. Forewing (distal abscissa of $R_{1} ; 2 R S, 3 R S, R S+M$, and $r$, wing vein). - e. Petiole. $-f$. Ovipositor sheath. g-i. Monoctonus nervosus, female. $-\mathrm{g}$. Ovipositor sheath. $-\mathrm{i}$. Petiole. $-\mathrm{h}$. Monoctonus paulensis, female ovipositor sheath. j-k. Monoctonus caricis, female. $-\mathrm{j}$. Ovipositor sheath. $-\mathrm{k}$. base of antenna $\left(\mathrm{F}_{1}, \mathrm{~F}_{2}\right.$ and $\left.\mathrm{F}_{3}\right)$.

The samples from A. toxicum bosniacum and A.pentheri with an aphid colony were reared until aphid parasitoids emergence. Adult aphids were preserved in $90 \%$ ethanol and $75 \%$ lactic acid 2:1 (Eastop \& van Emden 1972) for later identification.

Descriptive terminology used in this paper is based on Huber and Sharkey (1993) and Wharton et al. (1997).

\section{Results}

\section{Monoctonus leclanti Tomanović et Starý, sp. n.}

Diagnosis. The new species is similar to Monoctonus nervosus (Haliday) regarding wing venation, but it may be easily distinguished from the latter by its yellow coloration, narrower ovipositor sheath (Fig. 1f-h, j) and its chaetotaxy, prominent spiracular tubercles on petiole (Fig. 1e, i) and the number of antennal segments.

\subsection{Female}

Head. Eyes oval, medium sized, sparsely setose. Malar space equal to about $1 / 4$ of longitudinal eye diameter. Tentorial index (tentoriocular line/ intertentorial line) about 0.30 . Clypeus oval, with 9-11 long setae. Labrum with 5-6 setae. Maxillary palpus 4-segmented, labial palpus 3-segmented. Antenna 16-17-segmented, not thickened at apex (Fig. 1a). Setae on flagellomeres semierect, subequal to half segment diameter (Fig. 1b). Flagellomere $1\left(\mathrm{~F}_{1}\right), 4.5-5$ times as long as median width, slightly longer than $\mathrm{F}_{2}$, without or with single short longitudinal placode in upper part (Fig. 1b). Flagellomere $2\left(\mathrm{~F}_{2}\right), 3.0-3.3$ times as long as median width, with 4 longitudinal placodes (Fig. 1b). $F_{3}, F_{4}, F_{5}$ and $F_{6}$ with $6,6-8,6-7$ and 7 longitudinal placodes, respectively.

Mesosoma. Sparsely pubescent mesonotum with notaulices is distinct in the anterior part. Propodeum is areolated with clearly defined central pentagonal areola (Fig. 1c).

Forewing. Wing large, equal to body length. Stigma about 5.5 times as long as wide (Fig. 1d). Distal abscissa of $R_{1}$ (metacarpus) equal to $1 / 3$ to $1 / 4$ of stigma length. $\mathrm{RS}+\mathrm{M}$ vein distinct only in first quater, the remaining part colorless. 2RS colorless, with a small part near $\mathrm{RS}+\mathrm{M}$ vein effaced (Fig. 1d). 3RS and r veins distinct.

Metasoma. Petiole about 1.7-1.9 times as long as wide at spiracles. Spiracular tubercles very promi- 
nent (Fig. 1e). Dorsal disc of petiole rugose, with weak indications of middle longitudinal carina and with 4-5 long setae along the sides (Fig. 1e). Ovipositor sheath only moderately widened (Fig. 1f).

Colouration. Female largely yellow. Head: Eyes, temple and stemmaticum black. The remaining parts of head yellow to yellowish. Mouthparts yellow except mandible with dark apices. Scapus yellow, pedicel brown to yellowish, base of $F_{1}$ yellow, the remaining parts of antenna black. Mesosoma: Mesonotum black. Propodeum black, except yellowish upper areolas. All lower parts of mesosoma yellow. Legs yellow with dark apices. Wing venation brown. Metasoma: Petiole brown. First half of metasoma brown to light brown. Second half of metasoma yellow to yellowish. Ovipositor sheath yellow.

Body length: $3.0 \mathrm{~mm}$.

\subsection{Male}

Antenna 19-segmented. Head brown, except black eyes. Mesosoma black, except brown lower parts. Legs light brown. Petiole light brown. First half of metasoma brown. Second half of metasoma light brown.

\subsection{Etymology and type individuals}

Etymology. The name of the new species is given in honour of late professor Francois Leclant (Montpellier, France) who greatly contributed to the research of aphid diversity of Mt. Durmitor (Yugoslavia, Montenegro).

Holotype female. Yugoslavia, Serbia, Mt. Kopaonik — Metodje (1450 m), 20.VII.1999, reared from Delphiniobium junackianum Karsch. on Aconitum toxicum bosniacum, coll. O. Petrović. Holotype slide mounted and deposited in the collection of the Belgrade Natural History Museum (number 327/99).

Paratypes. Yugoslavia, Montenegro, Mt. Durmitor - Crno Jezero Lake (1400 m), 15.VIII.1997, one female, reared from Delphiniobium junackianum on Aconitum toxicum bosniacum, coll. O. Petrović (number 311/97); Yugoslavia, Serbia, Mt. Kopaonik - Metodje, 18. VIII. 1998, one male on A. toxicum bosniacum, coll. O. Petrović (521/98); Yugoslavia, Serbia, Mt. Kopaonik - Metodje, 20.VII.1999, 3 females on A. toxicum bosniacum, coll. O. Petrović(611-613/ 99); Yugoslavia, Montenegro, Mt. Durmitor Crno Jezero Lake, 19.VII.2000, one female on $A$. toxicum bosniacum, coll. Ž. Tomanović (101/00); Yugoslavia, Serbia, Mt. Kopaonik - Metodje, 7.VIII.2000, one female on Aconitum pentheri coll. Ž. Tomanović (107/00).

Paratypes deposited in the collections of the Belgrade Natural History Museum (4 females and one male, numbers 311/97, 611-612/99, 107/00 and 521/98) and P. Starý, České Budějovice, Czech Republic (2 females, numbers 613/99 and 101/00).

\subsection{Key to the related species, based on fe- males}

1. Ovipositor sheath gradually widened (Fig. 1f); prominent spiracular tubercles on petiole (Fig. 1e); body of prevalently yellow coloration; antenna 16-17segmented (Fig. 1a); labial palpus 3-segmented ......... Monoctonus leclanti sp. n.

- Ovipositor sheath ploughshare shaped (Fig. 1g-h, j); spiracular tubercles not apparent (Fig. 1i); body of prevalently brown coloration; antenna 13-16-segmented; labial palpus 3- or 2-segmented .................. 2

2. Antenna 13-14-segmented (Fig. 1k); labial palpus 2segmented; ovipositor sheath on Fig. 1j; Host aphids: Sitobion, Rhopalosiphum and Hyalopteroides ..... Monoctonus caricis (Haliday)

- Antenna 15-16-segmented; labial palpus 3-segmented; ovipositor sheath on Fig. 1g; Host aphid: Impatientinum balsamines (Kalt.) ... Monoctonus nervosus (Haliday)

\section{Discussion}

\subsection{Taxonomy}

Monoctonus leclanti belongs to Monoctonus nervosus species group (van Achterberg 1989) which is represented by $M$. nervosus and $M$. caricis in Europe, and its relatives in North America include $M$. paulensis (Ashmead), $M$. pacificus Pike and Starý and M. allisoni Pike and Starý (Smith 1974, Starý 1974, Pike et al. 2000, Pike et al. 2002). Within $M$. nervosus group, $M$. leclanti has a narrower ovipositor sheath. On the basis of this character, M. leclanti is somewhat closer to the genus Harkeria Cameron. 


\subsection{Parasitoid guild}

The host aphid, Delphiniobium junackianum is holocyclic and monoecious on Aconitum and Delphinium plants, and is distributed in West Palaearctic (Heie 1995, Remaudiére \& Remaudiére 1997). The parasitoid guild of $D$. junackianum was unknown until 1988, when several Aphidius ervi Hal. specimens were found and a new species from Italy - Aphidius sussi Pennacchio \& Tremblay was described (Pennacchio \& Tremblay 1988). Over the period 1997-2001, we collected 269 parasitoid specimens from $D$. junackianum. Aphidius sussi was the dominant parasitoid species (97\% of all parasitoids) and was found from June to September. Only 8 specimens of $M$. leclanti (3\%) were collected between mid-July and mid-August. Also, we gathered secondary parasitoids as follows: Alloxysta fulviceps (Curtis), Alloxysta victrix (Westwood), Alloxysta macrophadna (Hartig) (Cynipoidea: Charipidae), Coruna clavata (Walker) and Pachyneuron aphidis (Bouché) (Chalcidoidea: Pteromalidae).

Acknowledgements. The research was supported by Grant 03E04 (The Ministry of Science and Technology of the Republic of Serbia), Grant A6007105 (Grant Agency, Academy of Sciences of the Czech Republic) and from the Entomology Institute Project Z5007907 (Academy of Sciences of the Czech Republic). We express thanks to Aleksandar Stojanović from Belgrade Natural History Museum for identification of secondary parasitoids and Mrs. Gordana Tomović from Institute of Botany, Faculty of Biology, University of Belgrade for information about host plants.

\section{References}

van Achterberg, C. 1989: Revision of the subtribe Monoctonina Mackauer sensu stricto (Hymenoptera: Braconidae: Aphidiinae). —Z Zoologische Mededelingen, Leiden 63(1): 1-22.

Eastop, V. F. \& van Emden, H. F. 1972: The insect material. In: van Emden, H. F. (ed.), Aphid technology. Academic Press, London, pp. 1-45.

Gajić, M. \& Niketić, M. 1992: Aconitum L. In: Gajić, M. (ed.) Fam. Ranunculaceae A. L. Juss. — In: Sarić, M. (ed.), Flora Srbije 1, pp. 305-317. SANU, Odeljenje Prirodno-matematičkih nauka, Beograd.

Heie, O. E. 1995: The Aphidoidea (Hemiptera) of Fenno- scandia and Denmark. VI. - Fauna Entomologica Scandinavica, vol. 31: 1-222.

Huber, J. T. \& Sharkey, M. J. 1993: Structure. — In: Goulet, H. \& Huber, J. T. (eds.), Hymenoptera of the world: An Identification Guide to Families, pp. 13-59. Research Branch, Publication 1894/E, 1-688, Agriculture Canada, Ottawa, Ontario.

Kavallieratos, N. G., Lykouressis, D. P., Sarlis, G. P., Stathas, G. J., Sanchis Segovia, A. \& Athanassiou, C. G. 2001: The Aphidiinae (Hymenoptera: Ichneumonoidea: Braconidae) of Greece. - Phytoparasitica 29: 306-340.

Pennacchio, F. \& Tremblay, E. 1988: A new species of Aphidius Nees from Italy (Hymenoptera, Braconidae, Aphidiinae). - Boll. Lab. Ent. agr. Filippo Silvestri 45: $167-169$.

Pike, K. S., Starý, P., Miller, T., Graf, G., Allison, D., Boydston, L. \& Miller, R. 2000: Aphid parasitoids (Hymenoptera, Braconidae, Aphidiinae) of Northwest USA. - Proceedings of the Entomological Society of Washington, 102(3): 688-740.

Pike, K. S., Starý, P. \& Graf, G. 2002: Monoctonus allisoni n. sp. (Hymenoptera, Braconidae, Aphidiinae) and aphid-parasitoid guild for Nasonovia spp. (Hemiptera, Aphididae) in Northwest USA. - Proceedings of the Entomological Society of Washington, 104. (In press) Remaudiére, G. \& Remaudiére, M. 1997: Catalogue des Aphididae du Monde. — INRA, Paris.

Starý, P. 1974: Host range and distribution of Monoctonus nervosus (Hal.) (Hymenoptera: Aphidiidae). — Journal of Applied Entomology 75: 212-224.

Starý, P. \& Smith, F. 1976: The Nearctic distribution, host plants, and nomenclature of Monoctonus (Hymenoptera: Aphidiidae). - Proceedings of The Entomological Society of Washington 78(2): 171-175.

Starý, P., Tomanović, Ž. \& Petrović, O. 1998: A new parasitoid of root-feeding aphids from the Balkan mountains (Hymenoptera: Braconidae: Aphidiinae). Deutsche entomologische Zeitschrift 45: 175-179.

Tomanović, Ž. 2000: New findings of aphid parasitoids (Aphidiidae, Hymenoptera) from Serbia and Montenegro. - Acta Entomologica Serbica 5: 111-118.

Tomanović,Ž., Brajković, M. \& Krunić, M. 1998: A checklist of aphid parasitoids (Hymenoptera: Aphidiidae) in Yugoslavia. - Acta Entomologica Serbica 3: 95-106.

Tomanović,Ž. \& Brajković, M. 2000: Some rare species of aphid parasitoids (Aphidiidae: Hymenoptera) in $\mathrm{Yu}-$ goslavia. - Protection of Nature 52: 65-67.

Tomanović, Ž. \& Starý, P. 2001: Aphidius linosiphonis sp. n. (Hymenoptera: Braconidae: Aphidiinae), a new member of the aphid parasitoid guild associated with Galium. -ZOOTAXA 6: 1-4.

Wharton, R. A., Marsh, P. M., Sharkey, M. J. (eds.) 1997: Manual of the New World genera of the family Braconidae (Hymenoptera). - International Society of Hymenopterists, Special Publication 1. 439 pp. 